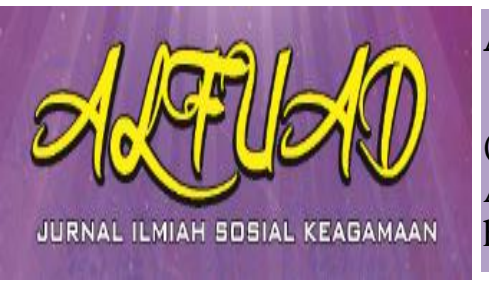

ALFUAD JOURNAL, 5 (1), 2021,(1-10)

(E-ISSN 2714-7606 P-ISSN 2614-4786)

Available online at

http://ecampus.iainbatusangkar.ac.id/ojs/index.php/alfuad

\title{
The Role of Religious Extenders in Improving Family Resilience in The Religious Affairs Office (KUA) Padang City
}

\author{
Fadil Maiseptian*) \\ Universitas Muhammadiyah Sumatera \\ Barat, Indonesia \\ E-mail: fmaiseptian@gmail.com

\section{Erna Dewita} \\ Universitas Muhammadiyah Sumatera \\ Barat, Indonesia \\ E-mail: ernadewit4@gmail.com

\section{Jasman} \\ Universitas Muhammadiyah Sumatera \\ Barat, Indonesia \\ E-mail: jasmanlimpur1987@gmail.com \\ *) Corresponding Author
}

\begin{abstract}
The high rate of divorce, especially in West Sumatra, is an important note for religious extension workers to increase their role and quality in providing counseling. Therefore, fast and progressive action is needed to overcome this. Another phenomenon revealed from the above data is that the divorce case is dominated by the wife's lawsuit. Therefore, it takes the role of religious counselors at the Office of Religious Affairs (KUA) to increase family resilience. The purpose of this study was to determine the role of religious instructors in increasing family resilience in the city of Padang from physical, social, and psychological aspects. Data collection techniques used interviews and were analyzed with the Miles and Huberman models following the stages of data reduction, data display, conclusion. The role of religious counselors in increasing family resilience has been carried out quite well, although not yet maximized because the raw materials are not yet available, the methods used are only advice and lectures and have not been evaluated continuously.
\end{abstract}

Keywords: Counselor, Islamic Gudance Counseling, Family Resilience

\section{INTRODUCTION:}

Realizing blessing family from a marriage requires careful preparation, both physically and psychologically. The Law of the Republic of Indonesia Number 1 of 1974 explains the purpose of having a family to form a happy and eternal family (household) based on God Almighty. In the process of living a married life, it is impossible if the husband and wife do not find problems. The rhythm of life that is getting faster makes family life full of pressure and competition, so that many then experience alienation from the ties that should provide warmth, because each one only indulges in ego and the domination of personal interests. Family life becomes dry and tasteless, so the family becomes vulnerable to various problems and conflicts that arise. These problems and conflicts if not resolved quickly will have an impact on divorce.

Based on data quoted from payakumbuhpos.com about the divorce rate in West Sumatra in 2018 it reached 7,000 cases. Of the seven thousand cases, 5,000 cases were sued by wives and 2,000 cases of husband's divorce. The wife's 
lawsuit is high because West Sumatra has maternal, matrilineal descendants. "The most common factors that cause divorce and rejection in West Sumatra are due to family disharmony or frequent fights. In addition, the next factors are economic factors and parties. (Matondang, 2014) explained that the cause of divorce was due to factors such as young age, economics, not having children and abusive husband behavior. So, these factors can also cause the loss of love for children and the estrangement of family relationships between the wife and husband.

Seeing the high divorce rate, especially in West Sumatra, it is necessary to take fast and progressive action to overcome this. Another phenomenon revealed from the data above is that divorce cases are dominated by the wife's lawsuit. This is indicated because of the economic independence of the wife so that they have a tendency to not be afraid to face divorce. Therefore, it takes a lot of increased knowledge and understanding for husbands and wives before entering the stage of marriage.

One of the preparation guidance needed by husband and wife is physical and psychological. This preparation is very helpful for husbands and wives in entering the marriage stage, so that they can survive if they encounter problems in marriage.
The ability to maintain the family is known as the resilience family. (Walsh, 2016) explains that family resilience is the ability of a married couple to maintain their family life in the face of problems and conditions that pressure themselves. This condition is also used as a means to develop oneself and relationships with others. Family resilience is related to aspects of beliefs, organizational patterns and communication processes.

Married couples to have good family resilience to carry out family life need help, direction and support from other parties. One of the parties who play a role in providing guidance for family resilience is the family counselor at the Religious Court Office (KUA). (Kusnawan, 2011) the task of religious instructors is to guide people in carrying out religious teachings, convey development ideas and increase harmony in life. Based on the duties of the religious instructor above, it is clear that one of the parties who have a role in increasing family resilience in the community is the religious instructor in the Religious Court Office.

Marriage contains a sacred and noble spiritual meaning that aims to worship God alone, and is a very important thing in human life because marriage is part of the perfection of one's religion, because with marriage the association between men and women becomes honorable and lawful 
according to sharia view. (Dariyo, 2004) explains that marriage is a sacred bond (holy or sacred) between the spouse of a man and a woman who has stepped on or is considered to have reached the age of maturity. This is in accordance with the position of humans as noble creatures (Subhan, 2017). Through marriage, each individual can realize mutual respect, help each other and protect each other.

To create a family as described in the paragraph above, it is necessary for every couple who will get married first to get pre-marital guidance from pre-marital counselors. This is so that each partner understands and understands is the source of problems in the household and how to deal with these problems properly. Family resilience is manifested not from families that do not have problems but from families who are smart and skilled in dealing with problems. Therefore, the role of premarital counselors is very important in increasing the resilience of sakinah, mawaddah and warahmah families, namely a peaceful family, full of love and blessed by Allah, the god almighty (Ismatulloh, 2015). The realization of family resilience is an important aspect in building the nation and state. Therefore, family resilience is the main foundation for realizing a safe, peaceful and prosperous social life. If the family that is part of the social community is tough, strong, happy, resilient and empathetic, then the happiness index of a society will also rise. Therefore, building family resilience is the responsibility of all parties, especially state institutions such as religious extension agencies in Religious Court Office throughout Indonesia, especially in the city of Padang. The purpose of this study was to determine the role of religious instructors in increasing family resilience in the city of Padang from the physical, social, psychological aspects.

\section{METHOD}

The method used in this research is field research. Field research is a method with field studies of phenomena and events seen at the research site (Sugiyono, 2015). This method is used to examine more deeply a phenomenon that is happening in the community. This type of research uses a case study that is by paying attention to all the backgrounds of a problem or individual interaction in two natural and natural social situations (Yusuf, 2013).

The selection of research subjects used purposive sampling technique. This technique uses certain considerations in selecting informants who are used as research subjects (Sugiyono, 2015). The consideration of taking research subjects based on the needs of this research is all religious instructors in the city of Padang. This is because they are functional staff 
who have been assigned by the Ministry of Religion in carrying out their duties as extension workers. The subject of this research does not apply to religious instructors outside the city of Padang because this qualitative study refers to the phenomena that occur in the city of Padang. Therefore, taking the subject of this research is called non-probability sampling (samples that do not provide opportunities for each element).

The data collection technique in this study used interviews. Interviews are a face-to-face communication process between interviewers and interviewees directly to obtain data and information according to research needs (Yusuf, 2013). The data analysis technique used in this study uses the Miles and Huberman model. Data analysis was carried out during data collection and after completion of data collection within a certain period (Sugiyono, 2015). The data analysis process is carried out with the stages of data reduction, data display and conclusion/verification.

\section{RESULT AND DISCUSSION}

Based on the results of interviews, the results of this study can be explained as follows:

\section{The Role of Religious Counselors in Improving Family Resilience in Padang City from the Physical Aspect}

Regarding food security in general, the Padang City Religious Counselor said that he had conducted outreach activities to the community for the last 6 months, with various counseling materials including providing enlightenment through lectures, socialization, motivating the prospective bride and groom about the responsibility for the welfare of the family, counseling about the process of family aquaculture, use of yard land and so on (Mr, Interview 24 August 2020). However, an evaluation of this outreach activity has not yet been carried out. Because in general the extension workers explain that they have never evaluated the activities that have been carried out so that the results achieved cannot be concluded with the level of success.

In the field of education, Padang City Religious Counselors generally explained that they had conducted counseling about the importance of education to the community in the last 6 months. The counseling materials provided also varied, such as teaching and discussing, providing motivation, teaching children to learn the Qur'an in the mosque, motivational Arabic lessons, coaching prayer services, lectures on educational motivation and online about the 
importance of education (Iir, Interview, 25 August 2020).

Based on the data described above, the role of religious instructors in realizing family resilience in terms of food security, education and health is still very minimal. This happens because there is no clear program, structured materials, activities are still carried out individually and there is no visible evaluation of the activities carried out in realizing family resilience from the physical aspect.

\section{The Role of Religious Counselors in Improving Family Resilience in Padang City from the Social Aspect}

The results of interviews about family resilience from the social aspect, the role of extension workers in increasing family social resilience can be seen from the efforts made to the development of non-physical resources, problem solving efforts, implementation of religious tasks, building good communication, maintaining and increasing commitment to taking care of the family and maintaining social relationships $(\mathrm{Wt}$, Interview 7 September 2020).

Regarding the role of extension workers in maintaining family social relations, in general, it has been done through lecture/discussion activities related to the importance of participating in social activities, maintaining social relations between two large families and with the community, material on the importance of togetherness and mutual respect (Ar, Interview 9 September 2020). In general, religious instructors have not explained in detail whether or not they have evaluated the activities that have been carried out in the context of maintaining family social relations (Jh, Interview 12 September 2020).

Based on the data described above, the role of religious instructors in the social aspect is quite good by providing counseling and enrichment of social material and participating in every general activity both within the family and the environment.

\section{The Role of Religious Counselors in Improving Family Resilience in Padang City from the Psychological Aspect}

In general, Padang City Religious Counselors have conducted counseling activities related to the ability of family members to manage and control the emotions of family members. Among the forms of activities carried out by religious instructors are giving advice/suggestions, consultations, lectures, providing material on emotional management, psychological guidance and providing BP4 material for prospective brides and grooms. Regarding the evaluation of this activity, in general, the religious instructor of the city of Padang has not explained in detail. Therefore, it is suspected that this activity 
has never been evaluated to determine the level of success (Ir, Interview. 4 September 2020).

With regard to fostering the ability to understand among family members, in general, the religious instructors in the city of Padang have also carried out several activities such as lectures, sermons, providing advice and counseling on BP4. It aims to create harmony in the household. However, it is suspected that this activity has not been thoroughly evaluated so that the follow-up of this activity has not been seen (Js, Interview, September 5, 2020). Based on the results of the interview above, religious educators have a fairly central role in the psychological resilience of the community.

\section{CONCLUSION}

Family resilience from the physical aspect is related to the family's ability to meet basic needs such as economic needs (clothing, food, shelter), education and health (Amalia et al., 2018). Based on Law number 52 of 2009 concerning population development and family development, it is stated that family resilience and welfare are conditions of tenacity, toughness, and material ability to develop themselves to achieve a harmonious and prosperous life (Syari et al., t.t.).

Physical security in terms of food, education and health will affect the harmony and well-being of family members (Santosa et al., 2020). Family physical resilience is the main requirement for family well-being, both emotionally and spiritually. Family members will be free from all forms of emotional problems if adequate nutrition, adequate housing, qualified education and good health (Lestari, 2015). Vice versa, worship will be carried out properly if the physical ability supports the implementation of worship. For example, prayer requires covering the genitals, charity requires the availability of money, worship requires knowledge and so on.

Therefore, it is very important the role of religious instructors in realizing family resilience from a physical point of view through various extension programs (Puspitawati et al., 2019) with wellstructured materials, because the role of religious instructors for the development of family resilience is very much, including: religion as a preacher who gives enlightenment (mubayyin) and guides the people towards the truth and a better life (Saeful, 2019). How to build an economy according to religious rules and how important education and health are from a religious point of view, all of these situations need proper motivation and explanation in order to filter actions in realizing family resilience. 
Furthermore, family resilience in the social aspect is manifested in the form of good social relations. Social relations are relationships that occur between individuals and individuals or between individuals and families or between families and families in a society, where each individual has different purposes, goals, desires and needs (Maputera et al., 2018). Family social resilience is also related to the ability to develop themselves and respond well to every challenge that exists. This condition is very vulnerable to the emergence of problems or social conflicts in the family so that the role of religious instructors as problem solving is needed. Although from the data described above it has been revealed that religious instructors in the city of Padang have carried out this activity, it is suspected that the activities have not been programmed properly because the implementation is still separated.

Improving family resilience through providing counseling about alleviating problems (Siahaan, 2012). In general, this has been done by the Padang City Religious Counselor through discussion activities and problem solving practices, consulting troubled families and counseling prospective brides and grooms. In general, evaluation activities have been carried out by religious instructors in the city of Padang and the results can be seen from the increase in the family Religious Court Office and changes for the better.

Then psychological resilience is the ability of family members to manage and control emotions so as to produce a positive self-concept and understand each other about family situations and conditions (Sunarti, 2015). So that it is expected to achieve satisfaction and fulfillment of family development tasks. From the psychological aspect of this family, it can be seen the ability of family members to manage/control emotions and mutual understanding between family members.

Psychological resistance from the aspect of emotional control and mutual understanding between family members is an important aspect to create calm, peace and tranquility in a family (L. Amalia, 2018). Emotional control is related to the ability of individuals to manage their potential, namely first, having selfawareness, namely the ability to understand one's own nature and know one's own way of thinking and being able to anticipate and react to situations and conditions in order to be more effective in maintaining family integrity (Irawati, 2015). Second, self-control in the sense of regulating the actions to be taken aimed at achieving emotional balance so that it has a positive impact on increasing family resilience (Khairunnisa, 2013). Third, 
being able to motivate oneself to be able to face and overcome obstacles that occur in family life (Sufni, 2018). Fourth, the ability to empathize, namely the ability to understand and feel how other people feel such as sadness, disappointment and so on (Wulandari et al., 2017). Therefore, the psychological resilience of each family member is needed to be able to control emotions intelligently. This is to minimize the possibility of quarrels and disputes that occur between family members if they are not able to manage emotions wisely.

Religious instructors as preachers who remind (mudzakkir) the community with their various knowledge of religious teachings, so that in fulfilling their needs they really understand the limitations. Third, religious counselors are mubasysyir or entertainers who are weak from various tests. Therefore, the presence of religious instructors should direct all people to have ideal personalities in realizing family physical resilience, such as the character of the personality of surrender, tenacity, patience and not easily discouraged.

Programs and counseling materials that have been well structured are BP4 counseling activities for prospective brides and grooms. Whereas problems will always exist as long as the family is still running, this means that family problem solving must be carried out on an ongoing basis. Therefore, religious educators have a comprehensive counseling program, not only pre-marital counseling but also postwedding counseling.

The psychological condition of family members, emotional control and mutual understanding between family members are benchmarks for the realization of family resilience. Therefore, the role of religious instructors is very important in directing or fostering the psychological condition of each family member. Fostering family resilience with clear programs, structured materials, evaluation and follow-up is very helpful for the realization of prosperity and happiness in the family

Based on the conclusions above, there are several suggestions that can be submitted as a follow-up to this research, namely: (1) Conducted scientific insight development activities for religious instructors at the Religious Affairs Office (KUA) in providing family resilience development for the community. (2) As a basis for the Ministry of Religion in improving the Religious Court Office of religious instructors in serving the community. (3) Further research is needed to create a module that can be used by religious instructors in increasing family resilience. 


\section{REFERENCES}

Amalia, L. (2018). Penilaian Ketahanan Keluarga Terhadap Keluarga Generasi Millenial Di Era Globalisasi Sebagai Salah Satu Pondasi Ketahanan Nasional. Jurnal Kesejahteraan Keluarga dan Pendidikan, 5(2), 159-172.

Amalia, R. M., Akbar, M. Y. A., \& Syariful, S. (2018). Ketahanan Keluarga dan Kontribusinya Bagi Penanggulangan Faktor Terjadinya Perceraian. Jurnal Al-Azhar Indonesia Seri Humaniora, 4(2), 129-135.

Dariyo, A. (2004). Psikologi Perkembangan Remaja. Ghalia Indonesia.

Irawati, D. (2015). Hubungan antara kesadaran diri dan efikasi diri dengan prokrastinasi akademik mahasiswa [PhD Thesis]. Universitas Muhammadiyah Surakarta.

Ismatulloh, I. (2015). Konsep Sakinah, Mawaddah Dan Rahmah Dalam Al-Qur'an (Prespektif Penafsiran Kitab Al-Qur'an dan Tafsirnya). Mazahib, 14(1).

Khairunnisa, A. (2013). Hubungan religiusitas dan kontrol diri dengan perilaku seksual pranikah remaja di MAN 1 Samarinda. Psikoborneo, 1(3).

Kusnawan, A. (2011). Urgensi Penyuluhan Agama Islam. Ilmu Dakwah: Academic Journal for Homiletic Studies, 5(17), 271-290.

Lestari, R. P. (2015). Hubungan Antara Pernikahan Usia Remaja Dengan Ketahanan Keluarga. Jurnal Kesejahteraan Keluarga dan Pendidikan, 2(2), 84-91.
Maputera, Y., Syafril, S., Anggreiny, N., \& Sarry, S. M. (2018). Membangun Ketahanan Sosial Keluarga Melalui Budaya Batobo.

Matondang, A. (2014). Faktor-faktor yang mengakibatkan perceraian dalam perkawinan. JPPUMA: Jurnal Ilmu Pemerintahan dan Sosial Politik UMA (Journal of Governance and Political Social UMA), 2(2), 141150.

Puspitawati, H., Azizah, Y., Mulyana, A., \& Rahmah, A. F. (2019). Relasi gender, ketahanan keluarga dan kualitas pernikahan pada keluarga nelayan dan buruh Tani "brondol" bawang merah. Jurnal Ilmu Keluarga \& Konsumen, 12(1), 112.

Saeful, U. N. (2019). Pengaruh Bimbingan Praktik Tilawah terhadap Motivasi Menghafal Al-Quran. Irsyad: Jurnal Bimbingan, Penyuluhan, Konseling, dan Psikoterapi Islam, 7(2), 211-232.

Santosa, A. D., Lastariwati, B., Sovitriana, R., Nilawati, E., \& Trisnawati, N. (2020). Ketahanan Keluarga Sebagai Pilar Pembangunan (Analisis Kualitatif Menggunakan Nvivo). Ikra-Ith Abdimas, 3(2), 6980.

Siahaan, R. (2012). Ketahanan sosial keluarga: Perspektif pekerjaan sosial. Sosio Informa, 17(2).

Subhan, S. (2017). Nalar Kesetaraan Mahar dalam Perspektif Syariah Islam. AT-TURAS: Jurnal Studi Keislaman, 4(1), 1-16.

SUFNI, Y. (2018). Strategi Komunikasi Interpersonal Guru dalam Memotivasi Diri Anak Berkebutuhan Khusus (Studi 
Terhadap Siswa Sd Negeri 5 Banda Aceh). ETD Unsyiah.

Sugiyono, S. (2015). Metode Penelitian Kuantitatif, Kualitatif dan RND. Alfabeta.

Sunarti, E. (2015). Ketahanan Keluarga Indonesia: Dari Kebijakan dan Penelitian Menuju Tindakan.

SYARI, D. D. D. K. F., M. S. D. S.-S., Hanafi, F. A., \& Negara, H. T. (T.T.). Kebijakan Pemerintah Tentang Perkembangan Kependudukan Dan Pembangunan Keluarga Persepektif Maqāṣid AsySyari'ah (Analisis Undang-Undang Nomor 52 Tahun 2009 Tentang.

Walsh, F. (2016). Trengthening Family Resilience (Third Edition). Guilford Press.

Wulandari, F., Rosidah, L., \& Maryani, K. (2017). Meningkatkan Kemampuan Berempati Anak Usia 5-6 Tahun Melalui Cooperative Learning. Jurnal Ilmiah Visi, 12(2), 163-169.

Yusuf, A. M. (2013). Metodologi Penelitian Kuantitatif, Kualitatif dan Penelitian Gabungan. UNP Press. 